THE new volume of the Geographisches Fahrbuch is of great value to scientific geography in its most comprehensive acceptation. Dr. Behm has been compelled to retire from the editor. ship, and is succeeded by Prof. H. Wagner of Göttingen, who, we have no doubt, will maintain the $\mathcal{F}$ ahrbuch at its previous high standard. The first part is devoted to the various geographical sciences. The first paper is by Prof. Zöppritz, "On the Present Standpoint of Physical Geography." This is followed by an account of recent researches in geographical meteorology by Dr. Haan; and papers on the Geographical Distribution of Animals and of Plants by Dr. Schwarda and Dr. Oscar Drade respectively. Prof. Bruhns summarises recent work in Europe in the measurement of degrees, and Herr Auwers gives the latitudes and longitudes of 144 astronomical observatories. Prof. F. v. Fritsch brings together recent investigations on the geographical distribution of geological formations all the world over; while Dr. v. Scherzer has his usual account of the world's commerce," and Dr. Gerland summarises recent advances in ethnological research. In the second part, which deals with general matters, Dr. Wagner has a thoughtful and useful article on the development of Methodik in geography; while, along with Herr Wichmann, he brings together a good deal of information on geographical societies, congresses, and journals. Thus it will be seen the new volume contains much matter of permanent interest.

WE have received Nos. 6,7 , and 8 (in one thick volume) of the Bulletin of the Union Géographique of the North of France. M. Leon Lacroix has a long paper describing a plan for the exploration of Central Africa, by the Wellé, a project we should much like to see carried out. M. Alf. Renouard, in a paper on the Geography of Flax, brings together much curious and useful information. Dr. Harmand's paper on the Races of Indo.China ought to interest ethnologists. Among the other contents are papers on the French in Indo. China, by M. Suerus ; Syria in I86o, by M. Huberdeaux; and a note on the Isthmus of Panama, by M. V. Daburcq.

THE principal paper in the January number of the Bulletin of the Paris Geographical Society (just received) is one of much research, by $M$. Dutreuil de Rhins, on the routes between China and India.

THE Mittheilungen of the Vienna Geographical Society con. tain an account of a botanical excursion in the north of the Caucasus, by M. P. Muromtzoff, and a paper on the Floods of the Winter of $1880-8 \mathbf{I}$, by Baron Stefanovic von Vilovo.

UÑDER the title of "Istruzioni Scientifiche dei Viaggiatori," the Italian Ministry of Agriculture, Industry, and Commerce have issued a very full and carefully compiled manual of information and instruction for travellers, edited by Signor Arturo Issel, with the collaboration of several specialists. The manual seems to us to combine the best features of all its predecessors in other languages, and ought to be of real service to all travellers who know Italian. It includes astronomy, meteorology, geography, and topography, deep-sea exploration, geolory and palæontology, anthropology and ethnology, zoology, botany, and mineralogy. It is published under the auspices of the Italian Geographical Society.

HeFT 4 of Band ii. of the Mittheilungen of the German African Society contains communications from Dr. Biichner and Herr Flegel. The former has been doing a considerable amount of exploration between the capital of Muato Janvo's kingdom and the Congo, though his progress has been hindered by the usual African difficulties. His collections have been very numerous ; unfortunately several boxes of them have been lost in the vessel in which they were being brought home, which was wrecked during the recent gales in the Channel. Herr Flegel has been doing some successful work on the lower and middle Niger.

Prof, Giuseppe Dalla Vedova has published the address he gave on the inauguration of the Chair of Geography at the University of Rome in November last. The subject is the Popular and the Scientific Conception of Geográphy. He shows that while the popular idea has its uses, the scientific conception is the only basis on which the subject can be studied with profit. $\mathrm{He}$ insists on the fact which has been frequently expounded in these pages, that geography has really become a sort of meeting-place for all the sciences, and that while topography may form the groundwork, it requires a knowledge of most of the physical and biological sciences to understand how the surface of the earth has reached its present condition.
DR. OsCAR Lenz has arrived in Berlin, where he has been lecturing on his journey across the Sahara to Timbuctoo.

AfTER all there seems to be little doubt that the news of the massacre of Col. Flatters and the other members of the TransSaharan Expedition is too true. Of course the project of a railway across the Sahara must be abandoned, in the meantime at least.

From Les Missions Catholiques we learn that news has at length been received respecting Père Law's expedition from Gubuluwayo, in Matabele Land, to Umzila's country, which was known to have met with some misfortune on the road. After passing the Insimbi Mountains the party reached the Great Sabi River, on the lower course of which we presume that Capt. Phipson-Wybrants died. The expedition journeyed, with their heavy waggon, along the left bank of the Sabi, meeting with country so difficult to traverse that in some parts they had to hew out of the rock a road for their waggon. Progress in this manner was terribly slow, and when that part of the Mashona country which owns some sort of allegiance to Umzila was reached, difficulties increased, as the natives did all they could to hinder their passage. Eventually on August 7, in a rugged pass where, surrounded by Mashonas, the missionaries were all doing their utmost to cut a road for the waggon, Père Wehl, by an accident not very clearly explained, got separated from his companions and was never seen again, though later news seems to have reached Gubuluwayo of his safety among a friendly tribe. Père Law and the rest of the party not unnaturally took fright at this, and leaving their waggon, escaped from their savage tormentors in the night. After about a fortnight's march they contrived to reach Umzila's kraal in a state of great exhaustion from fever and fatigue. They of course had to abandon almost all their property with the waggon, but further supplies have since been sent to them from Gubuluwayo.

Pére Depelchin, the head of the mission station at Gubuluwayo, has been for some time absent on an expedition beyond the Zambesi, and from his long silence it was thought that he too must have met with some serious accident. He appears, however, to have reached in safety an out-station at Tati in Matabele Land, but no account of his adventures has yet been received.

Mr. MCCALL, of the Livingstone (Congo) Inland Mission, is said to have formed a station at Manyanga, some 200 miles up the Congo, above the Yellala Falls, and he has no doubt about being able to reach Stanley Pool this year. The comparatively rapid progres; thus made by following the right bank of the Congo will probably induce the Baptist Missionary Society's party at San Salvador to alter their tactics and follow the line of the river, instead of wasting their energies in fruitless attempts to make their way by land through the hostile Makuta towns to Makwekwe, on the left bank of the Congo, above Manyanga, and so on to Stanley Pool.

THE French Geographical Society held its annual meeting on Friday, April 29, when Admiral La Roncière le Noury was elected president. On the occasion of a proposal to erect a monument to Col. Flatters and his companions it was resolved to inscribe on tablets the names of all the martyrs of geography who have lost their lives in any exploration in which the French Geographical Society has been interested.

DR. O. F. VON MÖLLENDORFF has just published separately at Berlin (Reimer) two maps which have been drawn from his surveys by Dr. Kiepert for the Berlin Geographical Society's Zeitschrift. One is an original map of the hill-country north and west of Peking, while the other embodies routes in the Chinese province of "Dshy-li" " and environs of Tientsin. Dr. Möllendorff, as - we have before mentioned, claims to be an authority on the subject of the transliteration of Chinese sounds, but we doubt if many people in this country will recognise in "Dshy-li " the name of the metropolitan province (Chihli), and yet the maps are issued with English titles.

\section{THE FUTURE DEVELOPMENT OF} ELECTRICAL APPLIANCES ${ }^{1}$

THE lecturer began by referring to our obligations to laboratory workers and the necessity for a larger endowment of original research. The applied science of the future lies in-

* Abstract of a lecture delivered by Prof. John Perry at a meeting of the Society of Arts, March 24. 
visible and small in the operations of men who work at pure chemistry and physics, and it is especially true of laboratory work in electricity that every day a man sees new lines of research opening up before him which his resources do not allow him to follow up.

In the applied science of electricity certain fixed laws tell us much about the future which is not generally known; and it is first necessary to become acquainted with these laws if we would speak of this future. By numerous experiments the lecturer showed that electricians are dealing with measurable things, and he gave in wall-sheets such information as seemed sufficient to give exact ideas in this matter to a popular andience. These wall-sheets had also been put in a printed form and circulated among the audience. The following is an example :-

\section{Wall-Sheet II.-Electrical Magnitudes} (SOME RATHER APPROXIMATE)

Resistance of

One yard of copper wire, one-eighth of

One mile ordinary iron telegraph wire

Some of our selenium cells ... ... ...

A good telegraph insulator

\section{Electromotive force of}

A pair of copper-iron junctions at a difference of temperature of $I^{\circ} \mathrm{Fahr} .=$

$0.002 \mathrm{ohm}$. ro to 20 ohms. 40 to $1,000,000$ $4,000,000,000,000$

Contact of zirc and copper $\quad \ldots \quad \ldots=$ One Daniell's cell $\ldots \quad \ldots \quad \ldots \quad \ldots=$ Mr. Latimer Clark's standard cell $\ldots=$ One of Dr. De Ia Rue's batteries .... = Lightning flashes probably many millions of volts.

Current measured by us in some experiments :-

Using electrometer ... $\ldots \quad \ldots=$ almost infinitely small currents. Weber.

Using delicate galvanometer $\ldots \quad \ldots=0.000,000,000,040$

Current received from Atlantic cable, when twenty-five words per minute are being sent

Current in ordinary land telegraph lines $\quad \ldots \quad \ldots \quad \ldots \quad \ldots \quad \ldots \quad \ldots$ Current from dynamo machine In any circuit, current in webers $\ldots$ = electromotive forc in volts $\div$ resistance in ohms.

Wall-Sheet III.-Rate of Production of Heat CalcuLATED IN THE SHAPE OF HORSE-POWER

In the whole of a circuit $=$ current in webers $\times$ electromotive force in volts $\div 746$

In any part of circuit $=$ current in webers $\times$ difference of poten tial at the two ends of the part of the circuit in question $\div$ 746.

Or, $=$ square of current in webers $\times$ resistance of the part in ohms $\div 746$

The distinction which must be made between electricity and electrical energy was dwelt upon, A miller does not merely speak of the quantity of water in his mill-dam; he has also to consider the height through which it can fall. A weight of one thousand pounds falling through a distance of one inch represents the same energy, that is, gives out the same amount of work in falling as one pound through one thousand inches. A mere statement then of the quantity of electricity given out by a machine is insufficient; it is also necessary to state what is the height or difference of potential through which it is falling. The quantity of electricity in a thunder-cloud is comparatively small, but the difference of potential through which this quantity passes when discharge occurs is exceedingly great. So it is with the two factors of the electrical energy developed by this glass machine. The quantity of electricity obtainable from this machine is comparatively small, but it is like a small quantity of water at an exceedingly great height, whereas in all these other machines we have, in the analogy of the miller, a very great quantity of water and a very small difference of level. I put this water analogy before you because you have all more or less exact notions about water, and because, within certain limits, the analogy is a very true one. I have traced it more fully in the wall-sheet. Of this and the other wall-sheets each of you possesses printed copies.

\section{WALL-SHEET I.}

We Want to Use Water. We Want to Use Electricity.

I. Steam-pump burns coal I. Generator burns zinc, or and lifts water to a higher level, uses mechanical power, and iifts electricity to a higher level or potential.

2. Energy available is, 2. Energy available is, amount of water lifted $x$ dif- amount of electricity $x$ differ. ference of level.

3. If we let all the water ence of potential.

3. If we let all the electricity flow away through channel to flow through a wire from one lower level without doing work, screw of our generator to the its energy is all converted into other without doing work, all heat because of frictional resist- the electrical energy is conance of pipe or channel. verted into heat because of resistance of wire.

4. If we let water work a 4. If we let our electricity hoist as well as flow through work a machine as well as flow channels, less water flows than through wires, less flows than before, less power is wasted in before, less power is wasted friction.

5. However long and narrow 5. However long and narrow 5. However long and thin
may be the channels, water the wires may be, electricity may be brought from any dis- may be brought from any dis. tance, however great, to give tance, however great, to give out almost all its original energy out almost all its original energy to a hoist. This requires a to a machine. This requires a great head. and small quantity great difference of potentials of water. and a small current.

After showing, by passing currents from two large Gramme machines through certain resistances and lamps, that electrical energy may be sent to a distant place and there converted into heat and light, the methods taken at the City and Guilds of London Institute for simultaneously measuring mechanical work, currents of electricity, resistance, the candle-power of electric lamps, \&c., were described, the dynamometers, photometers, \&c., being exhibited, as well as diagrams showing their construction. Actual measurements were made of the strengths of currents and the candle-power of an electric light. Many of the contrivances in use were invented by the lecturer and his friend Prof. Ayrton.

The transmission of mechanical power to a distance through the agency of electricity was illustrated by a number of experiments; the driving of a lathe and other machines, and proof that the motor which gives out power at the distant place produces a back electromotive force opposed to that of the generator.

"Now what do these examples show you? They show that if I have a steam-engine in my back yard I can transmit power to various machines in my house, and if you were to measure the power given to these machines you would find it to be less than half of what the engine driving the outside electrical machine gives to it. Further, when we wanted to think of the heating of buildings and the boiling of water, it was all very well to speak of the conversion of electrical energy into heat, but now we find that not only do the two electrical machines get heated and give out heat, but heat is given out by our connecting-wires. We have then to consider our most important question. Electrical energy can be transmitted to a distance, and even to many thousands of miles, but can it be transformed at the distant place into mechanical or any other required form of energy, nearly equal in amount to what was supplied? Unfortunately I must say that hitherto the practical answer made to us by existing machines is 'No'; there is always a great waste due to the heat spoken of above. But fortunately we have faith in the measurements, of which I have already spoken, in the facts given us by Joule's experiments and formulated in ways we can understand. And these facts tell us that in electric machines of the future, and in their connecting-wires, there will be little heating, and therefore little Joss. We shall, I believe, at no distant date, have great central stations, possibly situated at the bottom of coal-pits, where enormous steam-engines will drive enormous electric machines. We shall have wires laid along every street, tapped into every house, as gas-pipes are at present; we shall have the quantity of electricity used in each house registered, as gas is at present, and it will be passed through little electric machines to drive machinery, to produce ventilation, to replace stoves and fires, to work apple-parers, and mangles, and barbers' brushes, 
among other things, as well as to give everybody an electric light.

"Probably you think it very strange that I should show you the inefficiency of electric transmission of energy, and then make this very bold assertion. Well, the fact is that the ordinary electrical machines in use have not been constructed with a view to economy. They have been constructed to show that brilliant lights and considerable power may be produced from small machines. They have, at a comparatively small cost, attracted attention to the fact that electricity is an important agency. In so far they have done well; but on the other hand they gave rise to the well-known assumption that 50 per cent. of the mechanical power given to the generator was the maximum amount which could be taken from the motor. The true solution of the problem of transmission of power was, I believe, first given by Prof. Ayrton in his Sheffield British Association lecture. It had been supposed that to transmit the power of Niagara Falls to New York a copper cable of enormous thickness would be needed. Mr. Ayrton showed that the whole power might be transmitted by a fine copper wire, if it could only be sufficiently well insulated. He also showed that instead of a limiting efficiency of 50 per cent., the one thing preventing our receiving the whole of our power, is the mechanical friction which occurs in the machines. He showed, in fact, how to get rid of electrical friction. I will briefly give you our reasons. A machine at Niagara receives mechanical power, and generates electricity. Call this the generator, and remember that Wall-sheet III. teaches us that the mechanical power is proportional to the electromotive force produced in the generator, multiplied into the current which is actually allowed to flow. Let there be wires to another electric machine in New York, which will receive electricity, and give out mechanical work, as this machine does here. Now I showed you a little while ago that this machine, which may be called the motor, produces a back electromotive force, and the mechanical power given out is proportional to the back electromotive force multiplied into the current. The current, which is of course the same at Niagara as at New York, is proportinnal to the difference of the two electromotive forces, and the heat wasted is proportional to the square of the current. You see then, from Wall-sheet III., that we have the simple proportion-power utilised is to power wasted, as the back electromotive force of the motor is to the difference between electromotive forces of generator and motor. This reason is very shortly and yet very exactly given in Wall-sheet IV., a printed copy of which you all hold in your hands."

\section{WALL-SHEET IV.}

Let electromotive force of generator be $\mathrm{E}$; of motor F. Let total resistance of circuit be $\mathrm{R}$. Then if we call $\mathrm{P}$ the horse power received by the generator at Niagara. Q the horse-power given out by motor at New York, that is, utilised. $H$ the horse-power wasted as heat in machines and circuit. $\mathrm{C}$ the current flowing through the circuit.

$$
\begin{aligned}
C & =\frac{E-F}{R} \\
P & =\frac{E(E-F)}{746 R} \\
Q & =\frac{F(E-F)}{746 R} \\
H & =\frac{(E-F)^{2}}{746 R} \\
Q: H & :: F: E-F .
\end{aligned}
$$

"To put it more shortly still, the power wasted is proportional to the square of the current flowing, whereas the power utilised is proportional to the current, and also to the electromotive force of the motor. The greater, then, we make the electromotive forces, the less is the loss of power in the whole opera tion. Perhaps you will see this better from the water analogy. A small quantity of water flowing through a water-main may convey a large amount of energy, if it only has sufficient head. The frictional loss of power is independent of the head, but depends very much on the "quantity of water. In the model before you is the water analogy. Here is a reservoir, which I shall call A, kept filled with water by a steam pump, which draws the water from the sea-level, which I shall call $\mathrm{k}$. Water flows from reservoir $\mathrm{A}$ to distant reservoir $\mathrm{B}$, where it drives a tarbine giving out work due to its head B K. The current from $A$ to $B$, through the communicating pipe, is the same always, so long as A and B are at the same difference of level, and therefore the frictional loss of energy is always the same, whereas the work utilised from $\mathrm{B}$, by driving the turbine, increases proportionally to the height of $\mathrm{B}$ above sea-level. The result, then, to which the above laws led us was that for the future development of the transmission and distribution of electric energy it will be necessary to use electric machines of great electromotive force. Indeed so important must this principle become that we believe there is a future in this direction for the employment of even plate electrical machines, such as that of Holtz."

Then followed a discussion of methods of obtaining great electromotive force. Mr. Perry's own ways of carrying out these ideas are shown in his own dynamo-machine, which is large, has great speed, has no iron in its movable part, and has a commutator of small frictional resistance. Electric lighting and heating, telephones, and electric railways of the future were all spoken of as illustrations of the transmission of energy by electrical means, and as such they must be governed by the above principle.

It was then shown experimentally that electrical energy may be stored up in considerable quantities in an available form for future use, and the bearing of this fact on the future utilisation of great but variable natural sources of power, such as the wind and tide, was dwelt upon.

The remainder of the lecture was devoted to the importance of the principle of recurrent effects; one illustration was given as follows:- "If I very much alter the magnetic field in this telephone, by bringing a powerful magnet near it, with great care in listening I hear the faintest sigh, due to the diaphragm settling itself into a new position, its vibrations dying away as it does so; and if I brought a small magnet near, I should hear nothing. And yet the change of magnetism which produces the loud telephonic effects which we listen to is almost infinitely smaller. Why is this? It is due to the rapid recurrence of the effects. Now you are all aware of the importance of the telephone as a method of communication; I believe that a much greater importance is in store for it as a laboratory appliance."

The photophone and the method by means of which Messrs. Ayrton and Perry determined the index of refraction of ebonite, finding its square to be roughly the same as the mean value of its measured specific inductive capacities : the use of a powerful sub marine source of musical sound as a coast-warning which might be heard in a ship well above all other sounds, and the experiments which have been made by the lecturer and his colleague in this direction: these and other matters were discussed as examples of the use of the principle of recurrent effects. The lecture concluded by an account illustrated by experiments of Mr. Edward Bright's method of de-electrifying woollen yarn, and of Messrs. Ayrton and Perry's plan for seeing by electricity what is occurring at a distant place. A selenium cell moving over an image at, say, York, gave corresponding light and shade to corresponding parts of a screen at, say, London. Mr. Perry's York image was very simple, being a series of black, grey, and white squares, which were faithfully reproduced on the distant screen.

\section{MECHANICAL RESEARCH}

$\mathrm{TT}$ will be remembered that some time ago the Institution of Mechanical Engineers appointed a Committee to examine into three selected questions of research in matters pertaining to their profession. These researches are still in progress, but preliminary reports have been issued by the Committee, of which we propose to give a brief account.

The Hardening and Tempering of Steel.-One or two letters on this subject have lately appeared in our columns, and allusion has been made to the report by Mr. Wm. Anderson, presented to the Committee who were appointed specially to investigate this difficult question. Mr. Anderson's report, which contains much useful information in a comparatively small compass, is itself too long for our pages. We therefore give the following résumé of the question, taking Mr. Anderson's report as our basis :-

Whilst the theory of this subject is in a very vague and uncertain condition, the facts are exceedingly well known, and are daily applied in almost every department of arts and manufactures. Wherever steel tools are used it is necessary that they should be hardened and tempered; since the ordinary tool-steel s supplied chiefly from Sheffield, is too soft for catting and 